\title{
KONSTRUKSI REALITAS KEHIDUPAN KEDUA PEMAIN GAME ONLINE: STUDI PADA PARA PEMAIN GAME ONLINE DALAM MEMBENTUK REALITAS DAN KOMUNITAS VIRTUAL
}

\author{
Erni Herawati \\ Marketing Communication Department, Faculty of Economic and Communication, BINUS University \\ Jln. K.H. Syahdan No. 9, Palmerah, Jakarta Barat 11480 \\ erni-herawati@binus.ac.id
}

\begin{abstract}
Through the development information technologies, online gaming has become a means of communication and interaction between people. They build a virtual social world between them. The problem of this research is how the online game players build they second or secondary lives, particulary how they create second communities, identity, and space in virtual world. This research use qualitative method. The informants are from the online game player aand the data obtained from observation and interview. The results are second lives has a meaning as parallel wolrd that build as a the first world. This live is represents the imagination of the individual fantasy world that provided by online gaming developers.
\end{abstract}

Keywords: online game, second lives, virtual community

\begin{abstract}
ABSTRAK
Game online telah menjadi sarana berkomunikasi dan berinteraksi antar manusia seiring dengan perkembangan teknologi komunikasi. Mereka membangun dunia sosial secara virtual antar anggotanya. Permasalahan dalam penelitian ini adalah bagaimana pemain game online membangun dunia kedua atau dunia sekunder mereka, terutama bagaimana mereka membangun komunitas kedua, identitas kedua, dan ruang kedua melalui dunia virtual. Subyek dalam penelitian ini adalah pemain game online. Penelitian ini menggunakan pendekatan kualitatif dengan metode perolehan data melalui wawancara dan observasi. Hasilnya adalah kehidupan kedua memiliki arti sebagai bagian dari dunia paralel yang berjalan seiring dengan kehidupan pertamanya. Kehidupan ini merepresentasikan imajinasi dari setiap individu yang terwakili melalui dunia fantasi yang disediakan oleh produsen game online.
\end{abstract}

Kata kunci: game online, kehidupan kedua, komunitas virtual 


\section{PENDAHULUAN}

Komputer dan perangkat ICT (Information Communication Technology) lainnya telah menjadi sebuah media baru yang sudah terkonvergensi. Perkembangan tersebut mempengaruhi cara bagaimana orang berkomunikasi satu sama lain. Berbagai teori komunikasi yang telah ada dan dikembangkan dalam penelitian menjadi semakin cepat memerlukan penelitian baru karena berubahnya cara-cara manusia dalam berkomunikasi tersebut.

Mc.Quail membagi jaringan komunikasi yang digambarkan dengan piramida ke dalam enam kategori berdasarkan tingkatan proses komunikasi dan dari semakin banyak atau sedikitnya kasus komunikasi yang terjadi yaitu: 1) komunikasi intrapersonal; 2) komunikasi antar personal; 3) Komunikasi intra kelompok/dalam kelompok; 4) komunikasi antar kelompok; 5) komunikasi lembaga/ organisasi; 6) komunikasi jaringan masyarakat luas, termasuk disini adalah komunikasi massa. (Mc. Quail, 2011: 20). Apa yang dideskripsikan oleh Mc.Quail tersebut menjadi lebih membingungkan saat ini bila kita melihat bahwa konvergensi media telah mengaburkan batasan-batasan komunikasi, yaitu apakah komunikasi yang dilakukan manusia melalui media internet masuk dalam kategori komunikasi antar personal, komunikasi massa, komunikasi organisasi, komunikasi antar kelompok atau komunikasi dalam kelompok.

Menurut Bolter dan Grusin (2000) dan juga Lister, et al (2009), kemunculan internet dan juga persebaran mobile devices saat ini telah membuka terbukanya makna terhadap media massa dalam berbagai macam cara (Croteau, Hoynes, Milan, 2012: 288). Pertama, bahwa internet telah mengaburkan batasan antara audiens individu dan massa. Dari yang tadinya sifat komunikasi massa adalah one-to-many menjadi komunikasi many-to-many yang diperantarai oleh jaringan internet. Kedua, adanya pengirim atau komunikator yang diketahui dan penerima pesan yang sifatnya anonim menjadi hal yang problematik. Hal ini karena keduanya bisa jadi menjadi anonim ketika informasi sudah dikaitkan dengan website atau blog. Ketiga, komunikasi media baru sifatnya adalah interaktif karena dapat menciptakan feedback yang instan (Croteau, Hoynes, Milan, 2012: 288-289).

Internet adalah platform komunikasi dimana konten media digital dapat dikirimkan ke dalam berbagai macam alat, termasuk komputer desktop, wireless laptops, smartphones, dan mobile devices lainnya (Croteau, Hoynes, Milan, 2012: 288).

Jaringan internet yang diperantarai perangkat teknologi informasi yang terkonvergensi dilengkapi dengan kecepatan tinggi saat ini membuat manusia dapat menonton video, mendengarkan musik, dan berkomunikasi dengan keluarga, teman-teman, rekan kerja, dan kesenangan lain yang tidak didapatkan di perangkat komunikasi sebelumnya. Manusia di sela-sela aktivitasnya dapat berbagi pengalaman, kesenangan yang melibatkan adrenalin melalui game online yang ada dalam genggaman tangan mereka atau perangkat komputer personal mereka. Mereka dapat terhubung dengan siapa saja dengan kesenangan yang sama meskipun dengan mereka yang tidak dikenal di dunia nyata. Begitu mudahnya mereka terhubung membuat semakin meningkatnya jumlah manusia yang saling bergabung, sehingga pada akhirnya secara sadar atau tidak, mereka telah menjadi satu kesatuan masyarakat tersendiri yang berbeda dengan lainnya.

Sebelum beralih ke dunia virtual, fakta telah menunjukkan bahwa menurut Entertaintment Software Association tahun 2005 terdapat lima puluh persen dari semua orang Amerika memainkan video game (Baran, 2012: 359). Sedangkan menurut Stanley (2004) rata-rata pemain game online menghabiskan waktu 2 sampai 4 jam bermain dalam sekali duduk/satu waktu (Baran, 2012: 371).

Mereka yang bermaksud untuk tergabung dalam masyarakat virtual biasanya harus mempunyai identitas khusus supaya dapat bergabung dengan anggota masyarakat lainnya. Identitas ini 
tidak harus sesuai dengan identitas dalam dunia nyata, sehingga setiap orang bisa dengan bebas untuk menyebut dirinya dalam dunia virtual. Identitas kedua yang mereka ciptakan untuk tetap eksis di dunia virtual merupakan pintu untuk memasuki dunia kedua mereka, salah satunya adalah dunia game online. Melalui game online, mereka akan diajak untuk masuk ke dunia paralel yang berupa fantasi, yang berjalan seiring dengan dunia nyata mereka.

\section{Permasalahan}

Dari latar belakang tersebut di atas, maka permasalahan yang dapat diangkat disini adalah: Bagaimana pemain game online membangun dunia kedua atau dunia sekunder mereka, terutama bagaimana mereka membangun komunitas kedua, identitas kedua, dan ruang kedua melalui dunia virtual? Pembahasan disini akan lebih ditekankan pada bagaimana para pemain membangun dunia kognitif dan memisahkan dunia kedua mereka dalam kehidupan dan aktivitas mereka sehari-hari.

\section{METODE}

Penelitian ini menggunakan metode pendekatan kualitatif. Pendekatan kualitatif dipilih dikarenakan penelitian ini menekankan pada proses makna yang tidak dikaji secara ketat, menekankan pada sifat realita yang terbangun secara sosial, hubungan erat antara peneliti dan subyek yang diteliti. Peneliti yang menggunakan pendekatan kualitatif biasanya hendak mencari jawaban tentang cara munculnya pengalaman sosial sekaligus perolehan maknanya. (Denzin dan Lincoln, 2009: 6).

Subyek penelitian ini adalah para pemain game online dan mempunyai komunitas yang terbentuk melalui keberadaan game online yang mereka mainkan. Untuk mengumpulkan data, metode perolehan data yang dilakukan adalah melalui observasi dan wawancara. Observasi dilakukan agar dapat dilakukan analisa mengenai fenomena melalui keterlibatan peneliti dengan subjek yang diteliti, sedangkan wawancara berguna untuk mengungkap pengalaman, perasaan, tentang objek yang diteliti, selain itu juga untuk mengetahui motivasi dan perilaku subjek (Corbetta, 2003: 233). Teknik analisis data dilakukan sejak memulai observasi dan wawancara sampai dengan diperolehnya data. Analisis dilakukan secara berkelanjutan (Corbetta, 2003: 252).

\section{Kajian Literatur}

\section{Penelitian terdahulu}

Dalam observasinya tentang game online "Second Life", Gottschalk menjelaskan bahwa permainan tersebut adalah rumah virtual yang didiami setidaknya limabelas juta "residents" dari seluruh penjuru dunia, dimana mereka memunculkan dirinya sebagai avatar melalui situs yang tak terhitung jumlahnya. Dalam "Second Life", lebih dari dua ratus institusi yang ada di dunia nyata mempunyai bangunan virtual seperti perusahaan, institusi pendidikan, institusi media massa, dll yang semuanya digambarkan seperti kondisinya di dunia nyata (Gottschalk, 2010: 502). Hal ini juga seperti yang digambarkan oleh Willis (Willis, 2007: 13) bahwa ketika seseorang memasuki "Second Life" maka ia akan segera mengenali Yankee Stadium,Capitol Hill, banyak kampus universitas dan tokotoko virtual lainnya. Gottschalk menyatakan bahwa "Second Life is both a social psychological playground where participants enjoy individualistic fantasies and a virtual community where they collaborate on collective projects. When people define the virtual as real, it is real in its consequences" (Gottschalk, 2010: 501). Hal ini menjelaskan bahwa permainan virtual adalah tempat bermain yang mewakili fantasi individual dan juga komunitas virtual dimana mereka terlibat. 
Munn menyatakan bahwa sarana online dalam berpartisipasi, berinteraksi di dunia virtual atau jenis game MMORPGs khususnya "World of Warcraft" mampu menyediakan jenis aktivitas yang dimiliki bersama, dimana mempersyaratkan pengembangan pertemanan. Selanjutnya, disini sangat dimungkinkan bahwa tanpa adanya interaksi secara fisik untuk mengembangkan pertemanan antara orang-orang yang tidak pernah bertemu secara fisik sebelumnya, dan ini dilakukan semata-mata untuk berbagi pengalaman online secara bersama. (Munn, 2012: 9).

\section{Media Baru dan Game Online}

Lievrouw dan Livingstone (Mc. Quail, 2011; 42-43) lebih memilih untuk menyebut munculnya era teknologi informasi sebagai media baru yang karakteristik media ini menyatukan tiga elemen yaitu: 1) alat dan artefak teknologi; 2) aktivitas, praktik, dan penggunaan; 3) tatanan serta organisasi sosial yang terbentuk disekeliling alat dan praktik tersebut. Selanjutnya menurut Mc.Quail, ciri utama dari media baru adalah "kesalingterhubungan", aksesnya terhadap khalayak individu sebagai penerima maupun pengirim pesan, interaktivitasnya, kegunaannya yang beragam sebagai karakter yang terbuka, dan sifatnya yang ada “di mana-mana” (delocated). (Mc. Quail, 2011: 43)

Lister menyebutkan interaktivitas merupakan ciri utama yang menjadi nilai tambah dari media baru. Konsumen pada media lama bersifat pasif sedangkan media baru menawarkan interaktivitas, yaitu penggunanya mempunyai kekuatan untuk merasa terlibat dengan teks media, memiliki hubungan yang lebih independen dengan sumber-sumber pengetahuan, pemanfaatan media yang lebih individual, dan lebih banyak pilihan. (Lister, 2003:21).

Game Online merupakan salah satu wadah bagi manusia untuk berkomunikasi dan saling terhubung. Sifat komunikasi melalui game online ini melibatkan interaktivitas bagi pemainnya. Permainan disini melibatkan setidaknya dua orang atau lebih.

\section{Konstruksi Realitas Komunitas Virtual dalam Game Online.}

Semua manusia yang menggunakan media baru menyadari bahwa dunia yang digambarkan dalam game online adalah dunia fiksi. Realitas adalah hasil ciptaan manusia kratif melalui kekuatan konstruksi sosial terhadap dunia sosial dan sekelilingnya (Bungin, 2006:192). Begitu pula realitas dalam dunia maya merupakan bentukan manusia.

Dunia virtual menjadi elemen yang sangat diperlukan dalam memperantarai realitas terutama memungkinkan terbentuknya masyarakat digital. Masyarakat ini terbentuk tanpa memandang latar belakang sosial, etnis, maupun jender. Jutaan orang pengguna internet saat ini mendiami wilayah online yang cukup luas cakupannya. Mereka ini bisa jadi adalah creative designer, pengajar, pelajar, peneliti, pebisnis, pelaku event organizer, turis, pembeli, atau bahkan mungkin adalah gelandangan (Ensslin \& Muse, 2011: 1). Internet telah memfasilitasi bentuk-bentuk baru komunikasi dan interaksi sosial (Schaefer, 2011:146). Dengan teknologi, manusia dapat memelihara kehidupan sosial mereka secara elektronis, karena mereka tidak perlu kontak secara face to face. Kehidupan virtual benar-benar dapat dan telah bermigrasi kedalam kehidupan riil. Sosialisasi online tidak terlalu mementingkan prasangka orang (Schaefer 2011:115).

Pengertian masyarakat secara umum dapat dipahami seperti yang dikatakan oleh Bungin, yaitu: Masyarakat (community) adalah kelompok-kelompok orang yang menempati sebuah wilayah (teritorial) tertentu, yang hidup secara relatif lama, saling berkomunikasi, memiliki simbol-simbol dan aturan tertentu serta sistem hukum yang mengontrol tindakan anggota masyarakat, memiliki sistem stratifikasi, sadar sebagai bagian dari anggota masyarakat tersebut serta relatif dapat menghidupi dirinya sendiri. (Bungin, 2009 : 163) 
Pengertian tersebut menunjukkan suatu dinamika masyarakat yang berlaku secara nyata, tetapi untuk memahami konteks masyarakat yang spesifik, terutama ketika membahas tentang cyber Community, maka Bungin (Bungin, 2009 : 164) menjelaskan bahwa masyarakat maya pada awalnya merupakan sebuah fantasi dari manusia tentang dunia lain yang lebih maju dari dunia yang dijalaninya. Fantasi tersebut merupakan suatu sisi dunia yang lain yang mereka ciptakan yang bersisi tentang nilai, citra, dan makna kehidupan manusia sebagai lambang pembebasan dirinya dari kekuasaan materi dan alam semesta. Sebagian besar anggota masyarakat maya merupakan penduduk tetap di dalamnya yang ditandai dengan kepemilikan identitas berupa alamat. Alamat ini dapat berstatus sebagai penyewa atau pemilik, yaitu berupa e-mail, website, atau provider. Mereka setiap saat dapat memanfaatkan alamat dan rumah mereka dalam berinteraksi dengan sesama anggota masyarakat maya untuk memenuhi kebutuhan mereka.

Apabila dikaji dari sudut pandang komunikasi dan budaya, di dalam dunia maya kita dapat melihat bahwa orang mulai membentuk komunitas sosialnya untuk membentuk suatu in-group untuk menampilkan identitas sosial dalam kelompoknya tersebut. (seperti bagaimana cara merasa dan berpikir tentang dunia) (Thurlow, dkk, 2004:41)

\section{Kehidupan Kedua dan Identitas Virtual}

Kehidupan kedua (Second life/lives) disini adalah sebuah terminologi yang konotasinya dapat dikaitkan dengan salah satu game online yaitu "Second Life ${ }^{T M}$ " tetapi sebenarnya adalah istilah untuk menunjukkan bahwa terdapat kehidupan pertama (First Live) yaitu actual live, selain kehidupan virtual. (Ensslin dan Muse, 2011: 8).

Ensslin dan Muse menjelaskan bahwa terminologi kehidupan kedua tidak hanya membahas mengenai keberadaan game itu sendiri, tetapi menunjukkan fakta adanya identitas dan perilaku alternatif yang muncul dan dinegosiasikan maknanya dalam wilayah ontologi virtual yang luas. Selain itu juga mensyaratkan adanya perbedaan antara yang virtual, faktual dan nyata. (Ensslin dan Muse, 2011: 3). Keduanya juga mengutip pendapat Milgram dan Calquhoun (1999) yang menempatkan pengalaman antara yang nyata dan virtual dan melihat bagaimana teknologi benar-benar telah membentuk realitas. (Ensslin dan Muse, 2011: 3).

Untuk lebih memahami apa yang disebut sebagai kehidupan kedua, dapatlah dijelaskan pemahaman tentang realitas tersebut melalui apa yang disampaikan oleh Bungin dalam menjelaskan hiper realitas masyarakat maya (Bungin, 2009, 177) bahwa sistem teknologi melalui media informasi telah menguasai jalan pikiran masyarakat. Media tersebut membentuk theater of mind dimana mereka secara tidak sengaja telah meninggalkan kesan siaran dalam pikiran penggunanya, sehingga ketika media tersebut dimatikan maka kesan tersebut akan selalu hidup dalam pikiran penggunanya seperti layaknya panggung realitas dalam benak mereka.

Untuk menganalisis permasalahan tentang fenomena kehidupan kedua, maka dapat dipakai pembagian pembahasan menurut Ensslin dan Muse yang meneliti para pemain game online "Second Life ${ }^{T M}$ " yaitu bagaimana para pemain game online menciptakan: 1) Komunitas Kedua; 2) Identitas Kedua; dan 3) Ruang Kedua. Komunitas kedua mencoba menggali bagaimana bentuk-bentuk baru pada bermacam pengguna dunia virtual, dan juga mempertanyakan identitas yang dikaitkan dengan avatar yang yang melekat pada pengguna dan bagaimana mereka membangun dunia sosial mereka (Ensslin dan Muse, 2011: 15-33). Identitas kedua fokus pada eksistensi online pada dunia virtual. Deskripsi tentang diri kita direpresentasikan secara grafis melalui avatar dan lingkungan sosial virtual disekelilingnya. Identitas tersebut meliputi pemilihan nama, penyesuaian bagian-bagian tubuh, dan pemilihan kostum. Termasuk di dalamnya pemilihan jenis kelamin avatar. (Ensslin dan Muse, 2011: 75). Ruang dalam dunia virtual dibangun dan merupakan imitasi dunia nyata, merupakan fantasi dan realitas alternatif. Dunia di sini mempunyai aturan main dan norma-norma tersendiri, termasuk diantaranya tujuan-tujuan ekonomi, seperti jual - beli item dalam game. Dalam ruang virtual, 
pengguna dapat mengekspresikan dirinya dengan merancang dan menciptakan ruang yang mendekati realistis dalam berinteraksi dengan lainnya. (Ensslin dan Muse, 2011: 145-147).

\section{HASIL DAN PEMBAHASAN}

Pembahasan hasil penelitian ini membagi analisisnya ke dalam tiga hal yaitu : 1) Komunitas Kedua; 2) Identitas Kedua; dan 3) Ruang Kedua. Terdapat tiga informan yang diobservasi dan diwawancara dalam penelitian ini. Informan pertama adalah laki-laki berusia 21 tahun, pemain game "Ayo Dance" yaitu permainan jenis simulasi berupa Online Dance Battle Game, disini setiap pemain dapat bertanding secara online. Informan kedua adalah perempuan berusia 20 tahun, pemain di game "Atlantika" sebuah permainan bertema strategi dan pertarungan (action). Informan ketiga adalah lakilaki, berusia 20 tahun, memainkan permainan "Dota" yang juga bertema strategi dan pertarungan (action).

\section{Komunitas Kedua}

Informan pertama menjelaskan bahwa selain memang ia gemar bermain dalam game online, motivasi lainnya adalah untuk mencari teman. Oleh karenanya ia mengenal beberapa pemain yang sebelumnya sudah terhubung dengannya di game online tersebut. Pada komunitas "Ayo Dance" rutin diadakan gathering yang diadakan satu bulan sekali, acaranya hanya ngobrol-ngobrol. Di situs gamenya sendiri ada ruang untuk berkomunikasi dengan sesama pemain yaitu di dalam cafe atau di ruang tunggu.

Informan kedua menjelaskan bahwa game yang ia mainkan memang termasuk dalam permainan kelompok, sehingga setiap anggota harus memiliki kelompok untuk bertarung dengan kelompok lainnya.

"Kalau kita tidak bisa main terus biasanya teman satu tim kita bisa menggantikan posisi kita, tapi dengan ID-nya sendiri yang penting secara jumlah kita tidak kekurangan. Satu orang bisa main dua karakter, dengan dua komputer, yang satu dimainkan sendiri yang satunya dengan otomatis. Kalau kita kena sama lawan kita bisa milih kita musti ngomong apa ketika kena tersebut, jadi ga harus teriak-teriak, seru aja.”

Informan menjelaskan, meskipun demikian ia tidak pernah bertemu langsung dengan teman satu timnya. Komunikasi bisa dilakukan lewat twitter atau facebook, karena memang ada komunitasnya. Untuk semua anggota bisa lebih dari 1000, tapi untuk tim kita bisa sampai 80 an ID yang bergabung. Dalam komunikasi di dunia nyata seringkali dipakai simbol-simbol yang biasa digunakan dalam dunia virtual dan hanya mereka yang biasa gabung dalam game online yang mengetahui dan bisa paham. Selanjutnya Informan ketiga mangaku bahwa dia mengenal dan memang pernah sengaja bertemu dengan beberapa pemain untuk mendiskusikan sebuah turnamen yang akan diadakan. Selebihnya tidak ada komunikasi yang intens dalam dunia nyata, hanya ketika memainkan game saja.

\section{Identitas Kedua}

Informan pertama menjelaskan bahwa untuk dapat masuk ke dalam dunia game online, hampir semua situs mensyaratkan tentang prosedur untuk $\log$ in dan kemudian memilih dan membangun karakter yang diinginkan. Tidak masalah baginya terlibat dalam permainan ini, meskipun sebagian besar permainan Ayo Dance didominasi oleh perempuan hal ini karena ia tetap bisa membangun karakter yang ia inginkan. Informan merasa dapat menghilangkan kepenatan dengan bermain game online. 
Informan kedua memilih karakter dewi cantik yang sakti, sekali pukul lawan langsung mati dalam Atlatika karena lebih mewakili imajinasinya.

"Dewinya cantik dan kostumnya bagus-bagus."

Permainan ini menurutnya seru karena gambarnya bagus, ada karakter-karakter seperti dongeng. Permainan ini sebenarnya menceritakan pertarungan, tokohnya adalah dewa-dewi dan manusia, terserah setiap pemain mau pilih karakter yang mana. Setiap karakter bisa memilih senjatanya masing-masing, pemain tinggal pilih karakter apa dan memilih paket apa, menurut informan.

"Kita tinggal pilih mau karakter dewa-dewi atau manusia, disitu ada macam-macam jenis dewa-dewinya dan manusianya seperti apa. Kemudian tinggal pilih kita mau mereka seperti apa, misalnya bajunya, senjatanya mau seperti apa, kita yang tentukan.”

Hampir sama dengan informan yang lain, informan ketiga menggambarkan bahwa dalam Dota karakter terdiri atas hero dan alien. Informan sendiri tidak terlalu terpaku pada satu karakter tetapi sering berganti-ganti karakter sesuai dengan kebutuhan tim dan setiap karakter punya kelebihan sendiri-sendiri.

\section{Ruang Kedua}

Untuk masuk ke dalam ruang virtual, setiap informan memerlukan waktu minimal lima jam. Informan pertama mengaku bahwa waktu yang dihabiskan untuk mengunjungi ruang virtualnya adalah rata-rata antara delapan sampai dengan 16 jam sehari. Informan kedua menghabiskan waktunya lima jam sehari dan bisa sampai delapan jam jika sedang tidak bekerja dan kuliah. Informan ketiga menyatakan minimal dalam sehari ia menghabiskan waktu lima jam, jika tidak sedang kuliah bisa lebih dari itu.

Untuk biaya yang dihabiskan, tidak semua informan rela mengeluarkan biaya. Informan pertama merupakan pemain yang rela mengeluarkan biaya yang cukup besar dalam memasuki dunia virtualnya, dalam sebulan ia bisa menghabiskan lima ratus ribu rupiah untuk membeli avatar. Menurutnya, jika ditotal sampai dengan saat ini pengeluarannya untuk Ayo Dance mencapai lebih dari lima juta rupiah. Ia pernah mengikuti turnamen game dan memenangkan uang sejumah lima ratus ribu rupiah. Jika ia sedang masuk ke dunia game-nya maka akan timbul perasaan bete dan bingung jika terpaksa harus keluar dari ruang yang sedang dimasukinya, meskipun game yang ia mainkan tidak begitu masalah jika ia keluar sewaktu-waktu.

Informan kedua termasuk yang tidak harus mengeluarkan biaya untuk memainkan game-nya. Ia mengetahui nilai identitas miliknya (ID) melalui experience yang telah ia bangun mempunyai nilai yang cukup mahal jika ia berniat menjualnya ke sesama pemain yang ingin segera menduduki level yang tinggi. Informan menyebutkan bahwa ID-nya saja bisa terjual sekitar dua juta rupiah, jika ditambah dengan tools yang sudah ia miliki maka harganya bisa mencapai lima juta rupiah di dunia nyata.

“...Saya belum pernah menjual tool yang dimiliki karakter saya ke orang lain, tapi kalau mau beli bisa saja, kita tinggal lihat karakter orang dan melihat apa yang dia punya kemudian kita tanya ke dia apakah mau menjual barang yang dia miliki atau tidak. Kalau setuju kita langsung transfer uangnya lewat rekening, pakai uang beneran. Harga setiap tools itu ya tergantung kesepakatan, dan tergantung pasar, meskipun di game nya sendiri sudah ada harga tiap barang, tetapi kita bisa transaksi dan tawar menawar dengan harga lain.”

Fenomena ini bisa menggambarkan bahwa kehidupan kedua dalam dunia maya telah naik dan terbawa ke dalam kehidupan pertama atau nyata. Apa yang diperdagangkan di dunia virtual dapat di 
“kurs” kan ke dalam mata uang rupiah. Selanjutnya informan menjelaskan bahwa keberadaannya di ruang virtual ketika sedang bermain membuatnya sering tidak konsentrasi dalam bekerja atau ketika kuliah jika permainan yang sedang ia mainkan belum selesai, atau menjadi kesal jika ia tengah bermain tetapi terpaksa harus menyudahi permainan.

Informan ketiga menjelaskan bahwa untuk bisa gabung dengan permainan Dota, pemain harus membayar sebesar lima puluh ribu sampai seratus ribu rupiah untuk setiap ID yang dipakai. E-mail hanya dipakai untuk verifikasi. Jika sudah masuk ke dalam permainan, maka anggota tim yang tergabung dituntut komitmen yang tinggi, sebab tidak begitu saja bisa keluar dari permainan. Hal ini karena permainan Dota harus diselesaikan hingga tuntas. Ketika seorang anggota keluar, maka peperangan di dunia maya terus berlanjut. Jika sudah keluar maka tidak bisa bergabung lagi karena sudah dikeluarkan. Hal ini menimbulkan informan tidak dapat konsentrasi dengan permainan jika ada gangguan ketika ia bermain dan akan merasa sangat kesal jika tidak bisa melanjutkan permainan.

\section{SIMPULAN}

Dari data dan hasil pembahasan dapat disimpukan bahwa kehidupan kedua memiliki arti sendiri bagi setiap informan yang diwawancarai terutama sebagai bagian dari dunia yang berjalan seiring dengan kehidupan pertamanya. Kehidupan ini merepresentasikan imajinasi dari setiap individu yang terwakili melalui dunia fantasi yang disediakan oleh produsen game online. Komunitas kedua adalah komunitas yang tidak selalu dikenal dalam kehidupan pertama, karena kenal dengan sesama anggota kelompok dalam kehidupan pertama bukan menjadi tujuan utama. Meskipun demikian keterlibatan masing-masing anggota dengan anggota lainnya melalui pertarungan telah menciptakan ikatan tersendiri bagi anggota komunitas untuk selalu terhubung secara virtual, ataupun dijelmakan dalam kehidupan nyata melalui turnamen-turnamen game online. Identitas kedua menjadi hal yang cukup penting dikaji karena merepresentasikan imajinasi pemain secara individual terhadap karakter fantasinya. Melalui karakter, pemilihan senjata atau tools, kostum, dll yang telah diciptakan dan dibangun, maka secara tidak langsung dapat diketahui karakter dari individu yang memainkan. Ruang kedua hampir selalu tidak ingin ditinggalkan oleh pemainnya. Jika ini terjadi secara terpaksa, maka pemain bisa jadi merasa tidak tenang dan tidak bisa menjalankan aktivitas dalam kehidupan pertamanya dengan tenang. Transaksi-transaksi yang terjadi dalam dunia virtual bisa ditransaksikan juga dalam dunia nyata.

\section{DAFTAR PUSTAKA}

Baran, S. J. (2012) Pengantar Komunikasi Massa. Melek Media dan Budaya. Ed. 5. Erlangga.

Bungin, B. H. M. (2009) Sosiologi Komunikasi, Teori Paradigma, dan Diskursus Teknologi Komunikasi di Masyarakat. Kencana. Edisi Pertama. Cet. $4 .$.

Corbetta, P. (2003) Social Research, Theory, Methods and Techniques. Sage Publications..

Croteau, Hoynes and Milan (2012). Media/Society. Industries, Images, and Audiences. 4th Ed. Sage Publications..

Denzin, N.K., Lincoln, Y. S. (2009). Handbook of Qualitative Research. Pustaka Pelajar. 
Ensslin and Muse (2011). Creating Second Lives, Community, Identity and Spaciality as Construction of The Virtual. Routledge.

Gottschalk, S. (2010). The presentation of avatars in second life: Self and interaction in social virtual spaces. Symbolic Interaction, 33(4), 501-525. doi:http://dx.doi.org/10.1525/si.2010.33.4.501

Lister, M. (2003). Et all. New Media, A Critical Introdustion. 2nd ed. Routledge. NY.

Mc. Quail, D. Teori Komunikasi Massa. Buku 1. Ed.6. Salemba Humanika. 2011.

Munn, N. J. (2012). The reality of friendship within immersive virtual worlds. Ethics and Information Technology, 14(1), 1-10. doi:http://dx.doi.org/10.1007/s10676-011-9274-6

Schaefer, R. (2011). T. Sociology, A Brief Introduction. Ed-9th. Mc.Graw Hill.

Thurlow, Crispin. Lengel and Tomic 2004). Computer Mediated Communication, Social Interaction and The Internet. Sage Publication.

Willis, H. (2007). The Unexamined Second Life Isn't Worth Living : Virtual Worlds and Interactive Art. Afterimage, 35(2), 13-16. 